\title{
From Fragment to Hypertext: Adding Layers of Reading
}

\section{Ernesto Priani and Ana María Guzman Olmos}

In this paper we will suggest that a hypertextual representation of the text allows us to show different temporal layers of reading and add new ones. We use the notion "layers of reading" as a metaphor to explain how, historically, each reading of a text creates a new layer, an independent "stratum of meaning" that is superimposed to a previous reading. The metaphor comes from geology, of course, but it is also found in software. When we first thought about "layers", we had in mind a Photoshop tool called layer that lets you draw over a figure you made before, without changing it. The way in which this tool works is by organizing your picture in levels, so you can see the entire figure, while you are working only in one part (or layer) of it, and it encapsulates the other parts. At the end, your picture is the conjunction of the layers you have opened and drawn, but in the middle of the drawing process you can choose to work with some layers instead of others, and, of course, open a new layer to draw in it.

Any given text is a layer of reading. It has references to other works and it is an effort to organize and expose a meaning of those works. It's evidence that someone has gathered and transformed his readings in a new text, in the way that bees collect pollen and turn it into honey as Erasmus describes reading (Cf. Vandendrope, 2009, 117). When we take the text and edit it as a hypertext, we can create layers from it in the same way the tool we just described does, making the connection between this text and its sources, and with subsequent readings of the text through history, and adding new notes and interpretations. Hypertext then makes the construction of a complex historical model of reading possible in a way that, resembling a rock, exposes temporal layers of reading.

To show how this notion of layers of reading works with the hypertext, we will use the Bologna/Brown online edition of the 900 theses of Giovanni Pico della Mirandola ${ }^{1}$, because Pico's text is an extraordinary model of a layer of reading, and the hypertextual edition shows how, from one layer, we can add new ones beneath and above Pico's text.

\section{I.- Pico's layer of reading}

Eucharius Silber published Pico's 900 Theses in 1486 in Rome. This text is formed by small paragraphs written around other philosophers' ideas that summarize Pico's statements. If we have to compare this text with some kind of modern publication, we could say that Pico has made a Tumblr, using that microblogging platform to collect in small

\footnotetext{
${ }^{1}$ We can have another example of layers of reading in the edition of Homer's Odyssey by The Perseus Project, in which we find annotations and translations added to the text from 1886 to 1919.
} 
sentences his readings about other philosophers' ideas. In any case, Pico describes his work in this way in the Prefacio:

The following Nine Hundred Dialectical, Moral, Physical, Mathematical, Metaphysical, Theological, Magical, and Cabalistic opinions, including his own and those of the wise Chaldeans, Arabs, Hebrews, Greeks, Egyptians, and Latins, will be disputed publicly by Giovanni Pico of Mirandola, the Count of Concord. In reciting these opinions, he has not imitated the splendor of the Roman language, but the style of speaking of the most celebrated Parisian disputers, since this is used by almost all philosophers of our time. The doctrines to be debated are proposed separately by nation and their sect leaders, but in common in respect to the part of philosophy -as though in a medley, everything mixed together.

The complexity of the text we have in front of us is this: on the one hand, the Theses are about a considerable diversity of topics from Dialectic to Cabalistic, and on the other hand, they are about a large group of authors from different philosophical traditions. This means that the 900 Theses are, first of all, an extraordinary collection of readings.

But how could we know the way in which Pico made those readings? How could we know, in general, how people approached a text in a determined epoch? We think that texts are the materialization of readings. This means we could find in a text the vestiges of how, at a specific time, people read with particular goals, certain intentions and specific tools.

Through its textual structure, literary style, and organization, the text makes the evidence of a specific reading form visible. In the case of philosophical works, like Pico's 900 Theses, this appearance of the reading in the writing is also an evidence of the way he did philosophy: because it shows its methodology of reading. In sum, the presence of all these elements in a text is what we call a layer of reading.

The 900 Theses represent the materialization of an enormous batch of Pico's reading material. If we could discover the footprints in the text of how he had approached its readings, we would find the nature of the layer of Pico's reading: its goal, intentions, tools, and, as a result, the way he did philosophy.

We know Pico's reading goal by his own declaration in the 900 Theses, but also through De hominis dignitate and a letter to Bienivieni of November 12 (Bori, 2000, 25), 1486: he reads for a public debate with theologians.

In fact, most reverend fathers, I was not unaware that this disputation proposal of mine, would reveal itself as grateful and enjoyable to all you, who favor the good arts and have been willing to honor this discussion with your very authoritative presence, as it would be, on the contrary, troublesome and unpleasant to many others. (Pico, De hominis dignitate, Paragraph, 161,)

The nature of his aim implies certain issues. Because it was he who proposed the debate, he was the one who defines the object, the style, and the organization of it through the structure of the 900 Theses. At the same time, in all these structural elements of the text he left traces of how he read: 
a) In the specific textual structure. In the thesis or conclusion, that is a fragmented and concentrated evidence of reading, we can see that he reads to produce a statement that synthesizes ideas. Reading for Pico is an act of collecting, summarizing, and memorizing (Farmer, 1998, 50).

b) In style of speaking. The so-called "Paris style," a less sophisticated type of Latin used among theologians, shows us that Pico reads to translate complex ideas in a comprehensible form (Baussi, 1996, 167).

c) In organization. Pico organizes the conclusions in two sets of paragraphs: one according to other philosophers' works, organized by nation and their sect leaders, and another according to Pico's own opinion. By doing so, Pico distinguished his own thought from that of others, in recognition of the authority of those he had read. The theses are gathered under the authority of someone that had not directly produced the sentence, but probably the idea.

Pico's reading practice is certainly different from ours, and also different from, for example, Hegel's. We can understand this differences because their goals and intentions are not the same, but also because the tools utilized to read are different. It is important to emphasize this difference because thinking about a layer of reading makes sense only in relation to others layers. It is in the limit with other practices where the particularities of a layer are shown.

In the nature of Pico's specific enterprise, we can see some determinations of the material conditions of texts. As Farmer has pointed out, the 900 Theses were published at a time when manuscripts were being replaced by printed books, with the consequent impact in the way Pico read. Farmer writes:

As we see in Pico, printing made more sources widely available than at any earlier stage of Western history, encouraging syncretically minded thinkers to incorporate increasingly broad bodies of traditions into their systems and rendering those systems progressively open to philological and scientific attack... (Farmer, 1998, 134).

If this is the result of having printed books, it is the partial legacy of the manuscript culture.

The oratorical and disputational rituals of pre-modern times served crucial mnemonic functions for intellectuals who even in privileged cases like Pico's rarely had access to the full range of sources they viewed as authoritative. How often the 'texts' that Pico set out to reconcile were inventions of reconstructive memory -a situation obviously easing any syncretic task- is underscored by the fact that numerous citations in Pico's theses can be shown to be loose paraphrases rather than exact quotations: Pico's famous eidetic memory, like those commonly ascribed to pre-modern intellectuals elsewhere, can be shown on hard textual evidence to have been an illusion (Farmer, 1998, 134).

At this point, we can see the nature of Pico's layer of reading: the incredible amount of references to authors, texts and topics, thanks to the printed books; the fascinating decision to organize them in a way that is neither historical nor temporal, but thematic, in the 
manner of one grouping notes to prepare a discussion; the intention to extract this knowledge and put it in a brief paragraph, written in a style that the opposition could understand and memorize, a practice from the manuscript tradition; its attribution to an authority instead of an author, itself the result of the conjunction between two material conditions of the text, printed books and the manuscript era. In sum, Pico's 900 theses have an extraordinary amount of information about how Pico read and, by extension, Pico's philosophical method.

\section{On how we read a fragmented text}

For us, modern readers of Pico's works, the particularities of the 900 theses imply a paradoxical challenge in this context: how do we read it? This is the most important question for those who study Pico's philosophy. The text of the 900 theses, because of its structure and organization, is not discursive or argumentative, and it is hard to understand for the modern reader. We do not have, as well, the clue that perhaps could explain the text as a whole: the public dispute.

But to read it, we have a determinate entity: the 900 Thesis is a printed book, and we read printed books as unified works, without regard of the nature of the text, and under the hypothesis that the unity of the text is result of the author's intention. These are elements of our reading practice that at the end are also determinations for the methodology we use to do research. On this Christian Vandendrope $(2009,144)$ says:

Once they are brought together in the material structure of a book, then, even texts initially conceived as fragments can no longer be read as disconnected pieces, since the nature of the collection in which they are included and their connection with the author automatically play a unifying role. Fragments in the world of the book and printed matter are thus always elements of a unified work, and they are read as such.

Scholars who have studied Pico in our time read the 900 Theses as an unified text. A consequence of this is the extraordinary ambition to understand why Pico had put all the Theses together in the way he did. Hence they follow two strategies to reconstruct "Pico's intentions". First, they suggest that we could read the Theses looking for an internal relation between the Conclusiones. For example Biondi writes: "Comunque il montaggio delle tesi ubbidisce ad un disegno -una <<occulta concatenatio>>- che é possibile esplicitare, contro ogni tentazione di considerarle una congerie senza senso" (Biondi, 1995, XVI)

Farmer has followed the same idea in his edition of the 900 theses:

Numerological patterns pervade the nine hundred theses, suggesting that another structure is hidden there. Moreover, that structure was apparently tied to some mystical and eschatological plan underlying Pico's entire project. The outlines of that plan become clearer when we recall the reverse historical order (as Pico understood it) of the first part of his text: The theses of the Latin scholastics are followed by those of the Arab, Greek, Chaldean, Egyptians, and Hebrew "nations." The importance of this sequence is suggested in both the Oration and Apology, which tell us that "all wisdom emanated from the barbarians to the Greeks, from the 
Greeks to us," and further in the Apology, where we find that the Hebrew Cabala contained "the secret declarations of God" and "the true sense of the Law received from the mouth of God" by Moses; in the Heptaplus, we find that Pythagoras and apparently Plato too drew deeply on this secret Mosaic wisdom (Farmer, 1998, 32).

The idea is that we can find a series of connections between conclusions, which organizes the 900 Theses in a more unified text. In this approach, each conclusion acquires sense in relation to other paragraphs, so they conform to an internal organization that reveals the author's intentions.

Secondly, scholars try to reconstruct Pico's mind by looking for the sources of its text, in order to restore Pico's reading and understanding of them. For instance, Farmer notices in the 45 conclusions according to Thomas that:

The order of these theses suggests that the first half or so were drawn from Thomas's Commentary on the Sentences, with the rest inspired by his De ente et essentia and various Aristotelian commentaries. Only the last two conclusions were apparently drawn from the Summa theologiae... He also includes theses to point out inconsistencies in Thomas's thought. A copy of Petrus Bergomensis's Concordantiae conclusionum in quibus Thomas de Aquino videtur sibi contradicere (1476) was apparently in Pico's library and may have been used in compiling this section (Farmer, 1998, 218).

For Farmer, Pico's readings of Aquinas in the 900 Theses refer to four different books. The first one, the Commentary on the Sentences, is in turn referring to another book, the Sentences of Peter Lombard. The last one, by Petrus Bergomensis, is a reading and fragmented reference to Aquinas's works. Under this reading, each conclusion is connected with others through the books they are extracted from, so we can complete Pico's 900 Theses finding the text referred to directly or indirectly by him, in order to make the text more readable, complete or unified, as a way to better understand how Pico thought. We can ask, with María Teresa Rodríguez $(2012,54)$, could this be the best model to understand Pico?

El estatuto ontológico del fragmento supone que en sí mismo, en su fragmentariedad, hace referencia a un "todo" y por ello su caracterización más propia es la incompletud. La historiografía filosófica, como hemos visto a partir del caso de Brucker, se ha impuesto la tarea ingente de restablecer el pensamiento completo de los filósofos a partir de los fragmentos. ¿Es ello una estrategia adecuada? ¿Evidencia o proporciona siempre un conocimiento significativo sobre estos autores y el momento particular en el que escriben?

What we think is that a hypertextual edition could be an alternate strategy to approach the 900 Theses in terms of being aware of the difference between the specific way Pico read and wrote philosophy. 


\section{The hypertextual edition}

The Bologna/Brown edition of the 900 theses (http://www.stg.brown.edu/projects/pico/) is organized following the structure proposed by Pico. There is a menu on the left of the screen that shows this structure. From there you can go to the pages in which you see all the conclusions Pico has grouped under one title, for example, the 45 Conclusiones secundum $\underline{\text { Thomas }}$ or the 71 Conclusiones paradoxe. From here, but also from the menu, you can go to each single conclusion, which has its own page. We have, then, the conclusion as both a unit and an organizational structure.

At the level of the conclusion, the edition enables readers to see notes written around each of the theses. These notes can be translations, text analyses, philological interpretations, connections between the theses, books or fragments of books that have been referred by Pico. The same unit allows readers to follow various researchers' approaches to the text and to recover different perspectives around each conclusion. At the end, the hypertextual edition of the 900 theses lets us see the whole structure of Pico's work, but also the completeness of the single conclusion as a text, and a different layer of reading. The central element here is this focus on the conclusion as the fundamental unit, an effect of hypertextuality. In a paper book we can't have each conclusion as an independent element of the book. All of them are part of a dominant organization that we take as a unit. As hypertextuality deconstructs this organization to its units, this order is seen only as an option.

This consequence of hypertextuality, the apparition of single units as complete text (the theses in this case, but it could be paragraphs, pages, poems, verses) is a clue to how we build our digital reading. What we see is what we read: a fragment. "The main feature of hypertext is discontinuity -the jump- the sudden displacement of the user's position in the text" says Aspen Aarseth $(2003,771)$. This discontinuity is also a fragmentation (From, Vanderdorpe (2009, 71):

In a text on paper, the paragraphs or blocks of information are arranged in sequence, and the reader can access them essentially through contiguity, relying on a number of tabular elements. In a hypertext, the various blocks of information may be distinct and autonomous and may be located on a single 'page' or on separate 'pages'.

In a hypertextual edition, the author doesn't play a unifying role, because the structure, the order of the theses in our case, is not an expression of Pico's mind, but a choice of the reader:

In a physical book, all the pages are present, but in the case of hypertext, they appear only at the request of the user. This creates a particular kind of reading situation, the main characteristic of which is that readers have to constantly make choices by clicking on one button or another to make various units of information appear. Each button, each hyperlink, is thus an invitation to move forward, a promise of content (Vanderdorpe, 2009, 133). 
That is the jump Aarseth refers to. And when this jump -the click to go to another fragmentis describing a text, we can ask: what is the text?

Imagine a book in which some of the pages appear to be missing, or the print is unreadable every 16 pages, or some of the pages are repeated while an equal number omitted. Even if this copy is the only one we ever see, we automatically assume that it is not supposed to be this way and that a more correct version exists. [...] We do this out of lack of respect of the copy; it appears to misrepresent the 'real' text, even if such a thing may never have existed. In short, we prefer the imagined integrity of a metaphysical object to the stable version that we observe (Aarseth, 2003, 764).

With this exercise of imagination, Aarseth questions the idea of a metaphysical perfection of the text, one in which, for example, Pico would explain all of his decisions collecting the theses. Instead he invited us to respect the text as it is. Following this proposition, and focusing on the 900 theses hypertextual edition, what we see is what the text is: a conclusion, one single conclusion that is a complete and independent text.

As we have already said, the hypertextual edition allows us, from this basic unit, to add annotations related to it. Each one of these annotations is a reading of the conclusion and it can correspond to our reading or to readings made by anybody in the present or in the past. In this way we are adding layers of readings, a stratum of meaning that becomes part of our present reading of the texts. Since we can add as many layers as we want, we can have, from one single conclusion, a complex methodological object reflecting the way that conclusion has been or could have been read. We can see the text, but we can see the history of how has been read as well.

For example: In the hypertextual edition of the 900 Theses, we can take a look to theses II.11.34. We can read the complete text of the conclusion, as we can with any other conclusion, but we can also see its Spanish translation made in 2010. We can see, as well, the previous textual comment on how to read id est $V$, as a $\mathrm{V}$ or a $\mathrm{U}$, made in 2002 . In this same conclusion we could add a note by Farmer or Biondi about the reference to the Theology of Pseudo-Dionysius the Areopagite in the text. And so on. By doing this, we won't only have Pico's text, but we will see something like a rock formed by strata of reading, in which Pico's text is only one stratum.

For us, this is a very interesting model of reading because we can see the history of a text through the ways in which it has been read. A digital edition could enable introducing different approaches to a text as a part of it in the same way Bernard Cerquiglini $(1999,75)$ thinks a digital edition could include the variants of a text. In this sense, we can see, referring to a single text, different ways to read it. For example: Pico refers to the ideas of an authority instead of an author. The contemporary reader prefers to refer the same ideas to an author and a book. With this simple difference we can see how reading has changed, and how important is to us to understand those changes. Pico thinks in terms of authorities; we, in terms of authors. 
The digital representations of a text allows to visualize this difference hidden before in preceding editions and studies, because previous to the digital edition it was impossible to show, in paper editions, the process of formation of this "sedimented reading rocks." Like the Photoshop tool, hypertext allows us to see some layers, encapsulate others and, at the same time, create new ones. In fact, it is by visualizing the layers that the opportunity to draw new readings arises.

We think the digital edition and the digital reading could create a philosophical methodology, based on the awareness of the historical construction of each layer of reading. This is, according to us, an opportunity for philosophy to develop a model of digital work that takes advantage of the layers of reading to study the history of thought.

\section{Works Cited}

Aarseth, Espen J., "Nonlinearity and literary theory" on The new media reader edited by Noah Wardrip-Fruin and Nick Montfort, MIT Press, London, 2003.

Bausi, Francesco, Nec rhetor neque philosophus. Leo S. Olschki editore, 1996

Biondi, Albano, "Introduzione", Conclusiones nongentae: le novecento tesi dell'anno 1486, L.S. Olschki, Firenze, 1995.

Bori, Pier Cesare. Pluralitá delle vie: alle origini del Discurso sulla dignidá umana di Pico. Feltrinelli Editore Milano, 2000.

Cavallo G., Chartier, R., Eds. Historia de la lectura en el mundo occidental, Taurus, México D.F., 2011.

Cerquiglini, Bernard. In Praise of the Variant: A Critical History of Philology, The John Hopkins University Press, Baltimore, 1999.

Farmer, S.A., Syncretism in the West: Pico's 900 Theses (1486) The evolution of traditional, religious and philosophical systems, MRTS, Arizona, 1998.

University of Brown, Conclusiones CM, 2012, <http://www.stg.brown.edu/projects/pico/index.php >

University of Brown, Universitá di Bologna, Pico Project, 2012, < http://www.brown.edu/Departments/Italian_Studies/pico/ >

Rodríguez, María Teresa, El Comentario a una canción de amor de Pico della Mirandola y su crítica a la ontología ficiniana, Tesis doctoral, UNAM, México D.F.

Vandendorpe, Christian, From Payprus to hypertext. Toward the Universal Digital Library. Translate from french by Phillis Aronoff and Howard Scott. University of Illinois Press, 2009. 